Nicholas B. Miller

\title{
Philosophical History at the Cusp of Globalization: Scottish Enlightenment Reflections on Colonial Spanish America
}

\begin{abstract}
This article contributes to the evaluation of how historical philosophers of the Age of Enlightenment reflected upon incipient processes and forces of globalization. Drawing upon assessments of colonial Spanish America by late eighteenth-century Scottish philosophical historians, including William Robertson, Lord Kames, John Millar, Adam Smith and David Hume, the article considers the challenges Enlightenment-era thinkers encountered in balancing universal accounts of mankind with extensive human difference in a context particularly defined by European-managed trade and migration flows. By emphasizing the challenges that individual philosophical historians confronted in narrating processes of cultural and national change in the Americas during the early modern period, this article reveals a core tension between two basic components of Enlightenment-era historiography: national character and progress.
\end{abstract}

The 'discovery' of the New World has long been heralded as an epochal event. Thinkers from the sixteenth century onwards judged it a sacred historical milestone. Spanish historian Francisco López de Gómara [c.1511-c.1566] went so far as to declare it "the greatest thing since the creation of the world, excluding the Incarnation and the death of He who created it" (Gómara 1552, dedication; Burke 1995, pp. 40 - 41). In the eighteenth century, Adam Smith recast this narrative in terms of global trading relations, naming this discovery as one of the "two greatest and most important events recorded in the history of mankind" (Smith 1776, vol. 2, p. 235), the other being the Portuguese rounding of the Cape of Good Hope. He likewise drew upon circulating early modern paradigms in designating 'the sacred thirst of gold' as the force "that carried Cortez to Mexico, and Almagro and Pizarro to Chili [sic] and Peru" (Smith 1776, vol. 2, p. 154). Smith situated the discovery and conquest of the New World as landmark events in the initiation of mercantile globalization, both being driven on by the rapacious desire of Europeans for profit. Yet other Enlightenment thinkers remained compelled by the events as watersheds in the global spread of Christianity. During the

Nicholas B. Miller, Universität Potsdam (UP) / Universidade de Lisboa

2 OpenAccess. (C) 2018 Nicholas B. Miller, published by De Gruyter. (cc) BY-NC-ND This work is licensed under the Creative Commons Attribution-NonCommercial-NoDerivatives 4.0 License.

https://doi.org/10.1515/9783110492415-015 
1760s and 1770s, the clerical historian William Robertson, Smith's friend and associate in Edinburgh, engaged in a systematic attempt to appraise the history of the New World as one of the planting of European social, cultural and religious forms overseas. First published in 1777 in two volumes as the History of America, Robertson's work placed its attention particularly on "the most splendid portion of the American story": that of "the discovery of the New World, and of the progress of the Spanish arms and colonies there" (Robertson 1777, vol. 1, p. vi).

While the contributions of the Scottish Enlightenment to the practice of history have recently been subjected to renewed attention, the engagement of its historical thought in reference to Spanish America has yet to be considered at length (Sebastiani 2013, pp. 1-102; Allan 2013, pp. 307-342; Quiro Chueca 2005, pp. 160 -163). This article addresses this gap by examining discussion of colonial Spanish America in historical works composed by a range of Scottish Enlightenment thinkers, including Henry Home (Lord Kames), John Millar, James Dunbar and James Beattie-along with Robertson and Smith-and thereby offers new insights into the comparative horizons of historical knowledge in the Scottish Enlightenment. In particular, they reveal aspects of these thinkers' contributions to what David Hume heralded the 'science of man', which ostensibly sought to derive practical political lessons from the philosophical synthesis of empirical evidence about societies across the globe and throughout history. The case study of Spanish America affords particular insights into how practitioners of the 'science of man' engaged in inter-regional comparison and grappled with the question of conquest-induced change in collective identities, or, as they rendered it, national character.

\section{Modes of narrating the Spanish conquest}

Latin America has tended to be marginalized in historical accounts adopting global frames of analysis. Budding world or global historians-and universal historians before them-have found it difficult to reconcile comparative methodologies based on relatively static core cultural zones (civilizations) with Latin America's mestizo formation. Rather than constituting a distinct core culture, Latin America tends to be viewed as a contact point of competing traditions: linked on the one hand, through many cultural similarities-from religion to language-to Europe and North America; and perceived on the other hand as a region with a distinct character, separated in terms of economic power and geopolitics from the Western core encapsulated in organizations like NATO (Feres Jr. 2008). 
In the age of Enlightenment, trajectories towards the 'two Americas' binarya wealthy, Protestant, English-speaking North opposed to a poorer, Catholic, Spanish- and Portuguese-speaking South-were still only embryonic. Two alternative paradigms predominated. One, championed by natural historians such as George-Louis Leclerc de Buffon and Cornelius De Pauw, took its lead from climatic and geological speculations to polemically dismiss America as a literally 'newer' world, defined by degenerative climatic conditions retarding the development of all living creatures. In the case of humans, this likewise impacted their intellectual and psychic faculties (Carbia 1943; García Cárcel 1992). Alternatively, America was taken as a laboratory of comparative settler colonialisms. In the case of Spanish America, the leyenda negra dovetailed with physical theses of American degeneration, subjecting Spanish American creoles to double demerits in the eyes of various European publics, borne from a decadent, un-Enlightened home culture (Spain) and as natives of a degenerative continent. Intriguingly, this led to a macrohistorical vision during the eighteenth century contrasting the glory of the two most extensive pre-Columbian civilizations (Mexico, represented by the Aztecs; and Peru, by the Incas) with a supposedly decadent and baroque Spanish colonial present. Contemporary anti-Spanish polemics of the Enlightenment, which saw Spain as the embodiment of all that was ill with the ancien régime, thus rendered the history of Spaniard influence in the New World as one of decadence and decline.

The history of European colonialism and expansion excited great interest in the Enlightenment for a diverse range of figures, from novelists and playwrights to historians and political economists. Spanish America held particular appeal as a shining example of these processes. In Abbé Raynal's critical history of European colonialism, the Historie des deux Indes, America featured as a poster child of the ills of conquest, plantation slavery and imperial rivalry. Scottish Enlightenment discussion of these phenomena tended to be less vociferous, in line with its generally conservative political orientation. Smith critiqued American plantation slavery as being economically counter-productive due to discouraging investments in productivity, but failed to voice much sympathy for the human lives it destroyed. His protégé John Millar was more vocal in this regard, concluding the third edition of his Origin of the Distinction of Ranks with hopes of the imminent abolition of slavery.

Whereas Smith and Millar discussed contemporary American conditions within their treatises on political economy and historical jurisprudence, Raynal and his co-writers, including Denis Diderot, did this through a politicization of the genres of the travel narrative and accounts of foreign lands. These genres had been the primary disseminators of information about the world beyond Europe ever since the first great drama of Columbus's stumbling upon the islands 
of the Caribbean. Jesuits and missionary learned men, soldiers like Bernal Díaz (who accompanied Cortés's invading force) and hybrid figures such as Garcilaso de la Vega (who defended the honor of his Inca ancestors by writing a description of the Inca empire before its fall) all produced descriptions of the distant lands they had the occasion to visit or belong to, covering matters ranging from epic battles to descriptions of government and attire. In the eighteenth century, imperial bureaucrats and natural scientists such as La Condamine, Antonio de Ulloa and Jorge Juan continued the practice of offering extensive descriptions of the inhabitants of the lands through which they travelled. These accounts contained much useful information, but for the most part lacked a historical dimension. They represented the political and economic orders of non-European and past societies (as was the case with the Aztecs and Incas) as basically static entities. The travel narrative offered a description of the conditions of a different place, not the patterns or processes of change operative in these places. Information about the Americas was additionally provided through early modern, 'great man'-focused historical narration, with the discovery as well as the conquests of Mexico and Peru presented as heroic endeavors led by Columbus, Cortés and Pizarro (Burke 1995, pp. 31-51).

\section{Staging Americans in stadial history}

Building upon the works of seventeenth-century French historian Jean Baudoin, a coterie of British historians from the mid eighteenth century onward (David Hume, Edward Gibbon, John Millar and William Robertson) sought to compose a different sort of history (Miller 2017). Rather than focusing on specific battles or illustrious leaders of the past, they charted broader stories of the rise and fall of empires and the transition of societies to different governmental, legal, economic and property orders. For our purposes here, the contribution of the clericturned-historian William Robertson is of prime interest. Robertson served as Principal of the University of Edinburgh for three decades during the height of the Scottish Enlightenment, and was well connected with all its major figures. Following the success of his History of Scotland (1759) and History of Charles $V$ (1769), Robertson turned his attention west to engage with Europe's expansion into America and the amalgamation of the Western Hemisphere into the European sphere of power (Lenman 1997, pp. 200 -201).

Events in the 1770s undermined the basic premise of Robertson's History. The American Revolution left it unclear how linked the western hemisphere would remain with Europe. In terms of public demand, the events certainly promised great public interest in a new history of the Americas-but at the same time, 
any critical comments about British colonial policy could be interpreted as acts of sedition, as unpatriotically siding with colonial rebels over a unified transoceanic British commonwealth. Striking a cautious balance between the two, Robertson limited coverage to Spanish America when he released the work in 1777. His broader ambition went unfulfilled. His son posthumously published his unfinished work on the British North American colonies in 1796 (Robertson 1796); Robertson never made much progress with the histories of the colonies of the other European powers. In any case, Robertson's main interests had already been oriented to Spanish America-as having the longest history in the region and as site to the most significant events. Robertson benefitted in this endeavor from a unique assortment of manuscript documents, direct testimony (via questionnaires) and an array of earlier published works that no historian of his generation had yet explored in such depth (Cañizares-Esguerra 2002, pp. 38-59). Crucial were Robertson's close connections with the British Ambassador to Spain, Lord Grantham, and the collaboration of his chaplain Waddilove (Lenman 1997, pp. 202-06).

Robertson's history of Spanish America ran to two volumes and eight chapters, but corresponded to three basic phases: the state of American peoples before the Spaniards (books IV and VII); the decisive turning points of discovery and conquest (I-III, V-VI); and the aftermath (VIII). Robertson began with discovery and conquest-unsurprisingly, given that they had long proven their power to captivate reader interest. The majority of Robertson's history of Spanish America consisted of exciting and well documented (albeit rather conventional) narratives of the adventures of Columbus, Cortés and Pizarro. Robertson's most innovative historiographical contributions came after these narratives, wherein he recounted the condition of the inhabitants of the Americas prior to the arrival of the Europeans. He separated the Aztecs and the Incas from the rest of pre-Columbian Spanish societies, categorizing the latter as 'savage' and the former as 'half-civilized'. He thereby situated American peoples within the framework of stadial history, which assigned various societies around the world to different temporal stages of development within a universal historical schema of material, moral and social progress (Sebastiani 2014; Berry 2011, pp. 2-19; Miller 2017). Stadial history aspired not to understand the unique, internal historical processes of change within individual societies, but rather to synthesize a universal process of social development out of dissonant testimony-one culminating at an end of history located in contemporary 'commercial' European society. Robertson and other practitioners of stadial history refurnished the ahistorical tendency of travel narration, providing putatively empirical evidence for a universal history of mankind. 
The development of the Spanish colonial order in the Americas was by Robertson's time a story centuries old. James Dunbar [1742-1798], Professor of Moral Philosophy at King's College, Aberdeen, described colonial society as a humiliating disaster for the natives of America, whom the Spaniards had shunted to a position below African slaves (Dunbar 1780, pp. 394-96). Dunbar wondered if the inhabitants of 'the empires of Peru and Mexico' would have chosen extinction over such a disgrace, should they have known their eventual destiny (Dunbar 1780, pp. 394-96). Dunbar did not tender a response to the famous essay competition of 1785 on whether the discovery of America had been beneficial or harmful to the human race, but was adamant about the devastating impact of discovery for the indigenous inhabitants of the Americas: "The pen drops from my hand, in reciting the enormities acted by Europeans in the new hemisphere" (Dunbar 1780, p. 396). Dunbar here pointed, albeit darkly, to the emergence of Spanish America out of the ashes of destruction, and the founding of a colonial society upon the basis of a racialized order that forced the indigenous inhabitants to perpetually relive their defeat.

There are at least two ways to understand why Dunbar expressed more sympathy for the plight of the descendants of the Inca and Aztec empires than for their European counterparts, the Spanish conquerors. One could ground his comments within a local, intra-European political context, attributing them variably to the leyenda negra, inter-imperial rivalry and Enlightened contempt for the Spanish Empire. Going deeper into the history of medial representations of other societies, we could alternatively emphasize the function of the Aztecs and Incas as compelling thinking devices for eighteenth-century thinkers to contemplate alternative forms of social order and governance.

Henry Home, Lord Kames [1696-1782], a prominent figure in the Edinburgh legal establishment and a vital link between wealthy Scottish patrons and philosophers, admired both the Aztecs and Incas, noting that "there never was a country destitute of iron, where arts seem to have been carried higher than in Mexico" (Kames 1774, vol. 2, pp. 97-98). Kames further wrote that the Incas held "an absolute monarchy [...] but the farthest in the world from being despotic: on the contrary, we find not in history any government so well contrived for good of the people" (Kames 1774, vol. 2, p. 96). Kames was relatively restrained in his praise. Aberdonian poet and moral philosopher James Beattie [1735-1803] declared that "every body has heard of the magnificence, good government, and ingenuity, of the ancient Peruvians" (Beattie 1771, p. 509). Farther afield, in Germany, the Cameralist thinker Johann Heinrich Gottlob Justi [1717-1771] brilliantly evidenced the potency of pre-Columbian American civilizations as exemplars of government. Admiring the efficacy of collectivist practices of national granaries and land redistribution, Justi praised the supposed lawgiver of the 
Incas as 'the second Lycurgus', going so far as to call him the better Lycurgus! (Justi 1762, p. 546)

Robertson's lengthy discussion of the 'Mexicans and Peruvians' began with the dismissive preface that neither society could be compared with the Romans, nor were either entitled to rank reproduced most of what had been written about their institutions and accomplishments without qualification (Kontler 2014, p. 140). It is likely that an early form of the chapter constituted the source base for Kames' commendation of both societies in his Sketches (1774). Adam Smith may have been the decisive factor behind Robertson's rhetorics, given that he was one of their greatest skeptics in the eighteenth century. As Christian Marouby has explored, Smith's marginalization of the achievements of pre-Columbian American societies arose from the contradiction they posed to his model of agricultural progress in his rendition of stadial history (Marouby 2007, pp. 85-102). Smith, inspired by local Scottish conditions, claimed that the domestication of animals was a necessary precondition to extensive agriculture. The empirical record of the indigenous inhabitants of the Americas openly contradicted this thesis. Not only was it widely noted that various tribes raised crops while lacking domesticated livestock, but the Aztecs and Incas were famed to have ruled over great empires of millions of inhabitants. In terms of the former groups, Smith suggested that plant-based sustenance was mere 'seasoning' to game, constituting simply a local variant of savagery. As for the Inca and Aztec, Smith mocked the limits of their contribution to the global economy. In the Wealth of Nations, he wrote that in spite of "all the wonderful tales which have been published concerning the splendid state of those countries in ancient times [...] all the ancient arts of Mexico and Peru have never furnished one single manufacture to Europe” (Smith 1776, vol. 1, p. 254). Robertson's fidelity to standing historical testimony prevented him from making such a brazen move as openly contradicting it. He affirmed that most of what had been written about the Aztec and Inca had been credible. Yet, in forcing a stadial interpretation of their societies, he stumbled into contradictions at the intersection of his competing ambitions of a providentialist history of America, an exhaustively documented history of the region, and a stadial history of the indigenous inhabitants of the Americas. 


\section{Robertson's millenarian and colonial disappointments}

As the Scottish Enlightenment's greatest advocate of global evangelization and the civilizing mission, Robertson was captivated by the early modern Spanish attempt to convert the inhabitants of the Americas. While incomplete, it marked the greatest extension of Christianity's global footprint in a millennium. In Robertson's providentialist understanding of human history, Spain's conquest of the Americas was part of a divine plan to extend Christianity globally. Like Smith and Millar, Robertson was highly critical of the colonial practices of plantation slavery, but his religious convictions made him sympathetic to European colonialism as a means of achieving the conversion of all mankind to Christianity.

The shortest part of the History of America was that which recounted the contemporary state of Spanish America. It was, however, the only extended treatment by a Scottish Enlightenment thinker of the colonial social order produced in the aftermath of conquest. Robertson was unsparing in his contention that Spain had failed to properly Christianize the indigenous people, blaming the spontaneous actions of men on the ground, rather than imperial design. Additionally, he was adamant that the Spaniards had squandered their fortune of American domination through economic incompetence and mismanagement. Robertson made sure to note that the tide seemed to have turned with the coming of the Bourbon kings. He lauded the administrative reform efforts of Carlos III and his father Felipe V, as well as their promotion of freer trade between the different lands of America (Robertson 1777, vol. 2, pp. 415-418). On a personal level, Robertson's praise of the Bourbon reforms might also be attributed to gratitude to Carlos III for tolerating his project of a history of the New World-though Robertson never managed to obtain access to manuscript materials sequestered at Simancas (Armitage 1995, p. 66).

Robertson recounted the social world of Spanish America through the prism of the sistema de castas, a complex status system that featured a spectrum of racial categories assigned mainly on the basis of racial descent, but also of individual distinction (Miller 2013, pp. 21-32). Robertson balanced two theories surrounding the emergence of mixed-race 'casta' peoples-an intentional politics of national integration on the one hand, and basic lust on the other:

As the court of Spain, solicitous to incorporate its new vassals with its ancient subjects, early encouraged the Spaniards settled in America to marry the natives of the country, several alliances of this kind were formed in the infant colonies. But it has been more owing to licentious indulgence, than to compliance with this injunction of their sovereigns, that this 
mixed breed has multiplied so greatly, as to constitute a considerable population in all the Spanish settlements. (Robertson 1777, vol. 2, p. 368)

Robertson sought to rigorously document his study and offered precise footnotes, including page numbers, to his sources. However, as was typical in the Scottish Enlightenment, these citations frequently held only a tenuous connection with the original claim of the source. Robertson cited three references in support of the claim that Spanish sovereigns ordered their subjects to mix; none, however, had actually made this claim themselves. In his citation of a recompilation of the Laws of the Indies carried out under Carlos II in 1680, and his two citations from Antonio de Herrera y Tordesillas's Historia general de los hechos de los Castellanos en las islas, y tierra-firme de el mar océano (1601-15), the closest assertion one can find is the order given to the early Governor of Hispaniola Nicolás de Ovando to promote Christianization through intermarriage-not explicit political vassalization!

Robertson speculated that Spaniards maintained the sistema de castas to intentionally excite racial tensions for their own advantages, fomenting hatred between Africans and Indians for purposes of colonial order. Dunbar repeated the point (Dunbar 1780, p. 394-95). The Spaniards "endeavored to prevent every intercourse that might form a bond of union between the two races" (Robertson 1777, vol. 2, p. 370). Unlike in other parts of the hemisphere, the black population in Spanish America allegedly resented native people and viewed themselves as closer to the white population than to the native population (Robertson 1777, vol. 2, pp. 369-70). Robertson saw this as emanating both from the black community itself as well as from Spaniard design: "By an artful policy"-both laws and injunctions-"the Spaniards derive strength from that circumstance in population which is the weakness of other European colonies" (Robertson 1777, vol. 2, pp. 369-70). The center of interracial tension in Spanish America for Robertson was Peru. Although the peninsular leadership persistently sought to have Indians accepted to priesthood and religious orders, Peruvian orders continually ignored them (Robertson 1777, vol. 2, p. 506). To Robertson, nothing demonstrated more the insurmountable 'hatred and contempt of the Indians among the Peruvian Spaniards' (Robertson 1777, vol. 2, p. 506). He thought this discord also defined relations between Indians and black people: "[although the] negroes seem to be more numerous [...] they maintain their ascendant over the Indians, and the mutual hatred of one to the other subsists with equal violence" (Robertson 1777 , vol. 2, p. 369).

Robertson also emphasized cleavages within the white (or Spaniard) population of Spanish America, beginning his discussion of the sistema with a distinction between peninsulares (Spaniards born in Europe) and criollos (Spaniards 
born in the Americas). It was here where he damned Spanish America as a decayed society. Robertson described creoles as:

languid and unenterprising: by the enervating influence of a sultry climate, by the rigour of a jealous government, and by their despair of attaining that distinction to which mankind naturally aspire, the vigour of their minds is so entirely broken, that a great part of them waste life in luxurious indulgences, mingled with an illiberal superstition still more debasing. (Robertson 1777, vol. 2, p. 367)

Due to their superiority complex derived from living in a caste-ridden society, they were unwilling to do any manual labor, and unlike peninsulares, who actually created new fortunes in the Americas, creoles merely lived off the inheritance of their predecessors (Robertson 1777, vol. 2, pp. 366-368). Robertson's discussion pointed to a great polemic that played out further afield in the Enlightenment in the 1760s and 1770s, following Cornelius de Pauw's publication of Recherches philosophiques sur les Américains in Berlin in 1767. As evidence that America was a degenerative land, de Pauw pointed to the inability of any American creole to make a single significant intellectual achievement! Robertson's rendering did not go this far, but recycled the general opinion in eighteenth-century Europe of the decadence of Spanish American creoles.

\section{Conclusion: Patriotism and the dilemma of the historical formations of national character}

Around the turn of the nineteenth century, contexts across America witnessed the rise of patriotic creole discourses that countered the degeneration thesis with patriotic celebrations of their own localities and communities (Entin 2013, pp. 19-34; Cañizares-Esguerra 2002). This refutation of climatism via regional identity formation was paralleled in the Scottish Enlightenment with the attempt to de-prioritize environmental explanations of human difference in favor of national character. While Scottish historians of the second half of the eighteenth century followed David Hume in understanding national character as a principal differentiator of peoples across the world, they did not possess a rigorous explanation of the effects of time and historical processes upon the emergence, formation and evolution of these characters. This followed in good part from their inability to fully escape climatic and geographical explanations of human difference. Hume's infamous speculations upon essential racial inequalities-that black people were naturally inferior to other varieties of man - did not constitute the path taken up by most of his Scottish Enlightenment suc- 
cessors. It betrayed, however, the limits of his own methodological consistency in his proposition of a science of man, given that it took the synthesis of all human experience as its starting point. The famously eclectic (and self-contradicting) Henry Home enthusiastically resorted to climate as one of many possible causes for any given historical facet, yet even the more rigorous Glaswegian Professor of Civil Jurisprudence John Millar was unable to fully escape its rhetorical power. In the introduction to the third edition of his Distinction of Ranks, Millar claimed that climate had little explanatory power: "How many nations are to be found, whose situation in point of climate is apparently similar, and, yet, whose character and political institutions are entirely opposite?” (Millar 1779, p. 13) Nevertheless, his natural history of mankind was unable to offer a convincing explanation for why national characters themselves changed outside of historical accident (Millar 1779, p. 14).

In the case of William Robertson, the absence of a historicized conceptualization of collective identity formations led to a conventional portrayal of Spanish American creoles and mixed peoples as crude versions of peninsular models. Rather than paying attention to how forces such as conquest and intermarriage could produce new national characters, Robertson drew upon two older discourses: (i) decadence, via latent civic humanist strictures of the consequences of extreme inequality; and (ii) heat-induced indolence, via climatism. Although Robertson noted with hope the recent reforms of the reformist Bourbon monarch Carlos III, he conjured a dismal image of contemporary Spanish America, rife with ethnic tensions, dominated by degenerate creoles and decayed from centuries of administrative and economic mismanagement. He had received more sympathetic testimony from people with actual experience in the Americas through a series of questionnaires he commissioned, but chose to ignore this testimony and to rely instead upon contemporary tropes. What Robertson reveals above all is the depth to which colonial American societies lacked concrete cultural identities in the eyes of eighteenth-century European observers. This lacuna was soon confronted. His original project of a magnum opus recounting the spread of European nations to the Western hemisphere was disrupted mid-composition by white elites in the British North American colonies. A generation of Spanish American creole thinkers reared in their would soon join their ranks. Incipient globalization processes would indeed deepen the mark of European institutions and epistemologies upon the rest of the world-but in different ways than Robertson anticipated. 


\section{Bibliography}

Allan, David (2013): “Identity and Innovation: Historiography in the Scottish Enlightenment". In: Bourgault, Sophie / Sparling, Robert (Eds.): A Companion to Enlightenment Historiography. Leiden: Brill, pp. 307-42.

Armitage, David (1995): “The New World and British Historical Thought”. In: Kupperman, Karen Ordahl (Ed.): America in European Consciousness, 1493-1750. Chapel Hill: University of North Carolina Press, pp. 52-75.

Beattie, James (1771): An Essay on the Nature and Immutability of Truth. Edinburgh.

Berry, Christopher (2011): "The Science of Man and Society in the Scottish Enlightenment". In: The Kyoto Economic Review 80. No. 1, pp. 2-19.

Burke, Peter (1995): “America and the Rewriting of World History”. In: Kupperman, Karen Ordahl (Ed.): America in European Consciousness, 1493-1750. Chapel Hill: University of North Carolina Press, pp. 33-51.

Cañizares-Esguerra, Jorge (2002): How to Write the History of the New World: Histories, Epistemologies and Identities in the Eighteenth-Century Atlantic World. Stanford: Stanford University Press.

Carbia, Rómulo D. (1943): Historia de la leyenda negra hispanoamericana. Buenos Aires: Consejo de la Hispanidad.

Dunbar, James (1780): Essays on the History of Mankind in Rude and Uncultivated Ages. London.

Entin, Gabriel (2013): “El patriotismo americano en el siglo XVIII: ambigüedades de un discurso político hispánico". In: Hébrard, Veronique / Verdo, Geneviève (Eds.): Las independencias hispanoamericanas. Madrid: Casa de la Velázquez, pp. 19-34.

Feres Jr., João (2008): La historia del concepto "Latin America” en los Estado Unidos de América. Santander: Universidad de Cantabria.

García Cárcel, Ricardo (1992): La leyenda negra. Historia y opinión. Madrid: Alianza.

Gómara, Francisco Lopez de (1552): Historia general de las Indias. Zaragoza.

Justi, Johann Heinrich Gottlob (1762). Vergleichungen der europäischen mit den asiatischen und andern vermeintlich barbarischen Regierungen. Berlin, Stettin, Leipzig.

Home, Henry, Lord Kames (1774): Sketches of the History of Man. 2 vols. Edinburgh.

Kontler, Lazlo (2014): Translations, Histories, Enlightenments. William Robertson in Germany, 1760-1795. New York: Palgrave Macmillan.

Lenman, Bruce (1997): “'From Savage to Scot' via the French and the Spaniards. Principal Robertson's Spanish Sources”. In: Brown, Stewart J. (Ed.): William Robertson and the Expansion of Empire. Cambridge: Cambridge University Press, pp. 196-209.

Marouby, Christian (2007): "Adam Smith and the Anthropology of the Enlightenment. The 'Ethnographic' Sources of Economic Progress”. In: Wolff, Larry / Cipolloni, Marco (Eds.): The Anthropology of the Enlightenment. Stanford: Stanford University Press, pp. 85-102.

Millar, John (1779): The Origin of the Distinction of Ranks. $3^{\text {rd }}$ edition. London.

Miller, Nicholas B. (2013): "La pintura de castas: An Enlightened Genre? An Enlightened Intent?” In: Dolánski, Dariusz / Janczys, Anna (Eds.): Images of/from Enlightenment. Zielona Góra: University of Zielona Góra Press, pp. 21-32.

Miller, Nicholas B. (2017): John Millar and the Scottish Enlightenment: family life and world history. Oxford: Voltaire Foundation. 
Quiroz Chueca, Francisco (2005): “Clío contra el imperio: Historiografía anglosajona sobre Hispanoamérica en los siglos XVIII-XIX”. In: Investigaciónes Sociales 9. No. 15, pp. $153-172$.

Sebastiani, Silvia (2013): The Scottish Enlightenment: Race, Gender, and the Limits of Progress. New York: Palgrave Macmillan.

Smith, Adam (1776): An Inquiry into the Nature and Causes of the Wealth of Nations. 2 vols. London.

Robertson, William (1775): “The Situation of the World at the Time of Christ's Appearance, and Its Connection with the Success of His Religion, Considered". In: The Scotch Preacher: or, a Collection of Sermons. 3 vols. Edinburgh.

Robertson, William (1777): The History of America. 2 vols. London.

Robertson, William (1796): The History of America, Books IX and X, Containing the History of Virginia to the Year 1688; and the History of New England to the Year 1652. London. 
